\title{
Efficacy of serotonin receptor agonists in the treatment of functional dyspepsia: a meta-analysis
}

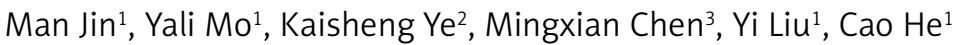

${ }^{1}$ Department of Medicine, Hangzhou Seventh People's Hospital, Zhejiang, China ${ }^{2}$ Hangzhou Wengjingtang Combination of Chinese Traditional and Western Medicine Clinic, Zhejiang, China

${ }^{3}$ Department of Digestive Diseases, Chinese Traditional Medicine Research Institute of Zhejiang Province, China

Submitted: 23 August 2016

Accepted: 1 January 2017

Arch Med Sci 2019; 15, 1: 23-32

DOI: https://doi.org/10.5114/aoms.2017.69234

Copyright @ 2017 Termedia \& Banach

\section{Abstract}

Introduction: Functional dyspepsia (FD) is typically treated with serotonin receptor (5-HT) agonists such as cisapride, mosapride, tegaserod and tandospirone citrate. However, there are conflicting efficacy data, possibly due to significant heterogeneity between studies. In this meta-analysis, we analyzed the efficacy and safety data from studies evaluating the efficacy of serotonin receptor agonists in patients with FD.

Material and methods: Relevant studies were selected from the Medline, Cochrane, EMBASE, and Google Scholar databases. The meta-analysis included 10 RCTs which evaluated the efficacy of serotonin receptor agonists in patients with FD (final total of 892 patients in the serotonin receptor agonist group, and 640 participants in the placebo group). The primary outcomes were the response rates and abdominal symptoms score. The Cochrane Collaboration's tool was used to assess risk. Sensitivity analysis was carried out using the leave-one-out approach.

Results: Patients treated with serotonin receptor agonists had a significantly higher response rate compared to placebo-treated patients (pooled OR = 2.99; $95 \% \mathrm{Cl}: 1.15-7.77 ; p=0.025)$. Patients treated with serotonin receptor agonists had a significant improvement in symptom scores compared to the placebo group (pooled standardized mean difference $=-0.43 ; 95 \% \mathrm{Cl}:-0.83$ to $-0.04 ; p=0.031)$. Sensitivity analysis indicated that the pooled estimates for abdominal symptom score might be affected by the Yeoh et al. (1997) study. Conclusions: Serotonin receptor agonists had a significantly higher efficacy compared to placebo in the treatment of FD.

Key words: functional dyspepsia, serotonin receptor, efficacy, placebo, meta-analysis.

\section{Introduction}

Functional dyspepsia (FD) is defined as the presence of one or more of four gastroduodenal symptoms including epigastric pain, epigastric burning, postprandial fullness, and early satiety, in the absence of organic disease [1-3]. Functional dyspepsia affects approximately $21 \%$ of the population worldwide [4]. Although the etiology and pathophysiology of FD are not well understood, recent studies have suggested that abnormalities in gastrointestinal motility, abnormal sensorimotor function (hypersensitivity to distention and impaired meal accommodation), genet-

\author{
Corresponding author: \\ Kaisheng Ye \\ Hangzhou Kanghui \\ Combination of \\ Traditional and \\ Western Medicine Clinic \\ 310019 Zhejiang, China \\ Phone: 15397010817 \\ Fax: 0571-58123951 \\ E-mail: \\ yekaisheng1025@163.com
}


ic factors, psychosocial factors, and Helicobacter pylori infection may be implicated in the pathophysiology of FD [5]. Helicobacter pylori infection is more common among FD patients than healthy controls [6]. However, the effect of $H$. pylori eradication therapy on the clinical outcome of FD patients remains unclear [7-9].

Therapeutic strategies for FD include the use of histamine $\mathrm{H} 2$ receptor antagonists, mucosal protection agents, tricyclic antidepressants, and H. pylori eradication therapy [10-12]. Classification of FD as epigastric pain syndrome (EPS) or postprandial distress syndrome (PDS) aids in development of management and treatment strategies. Patients with EPS are typically treated with proton pump inhibitors (PPIs) [13], while first line therapy in patients with PDS includes prokinetics such as domperidone and itopride (dopamine receptor antagonists), and cisapride, tegaserod, or mosapride (serotonin type 4 receptor (5-HT4) agonists), which stimulate gastric smooth muscle contractions $[14,15]$. The 5-HT4 receptor is mainly found in the intestine, and has been shown to increase gastric volumes before and after a meal in healthy volunteers, as well as impacting gastric motor and sensory function in patients with FD [16]. 5-HT4 receptor agonists have also been shown to significantly attenuate visceral pain arising from the colon [17].

A number of studies have evaluated the efficacy of serotonin receptor agonists for treating FD. A dose-finding study showed no significant difference in efficacy of different doses of mosapride (a 5-HT4 agonist) compared to placebo [18], and a single dose of mosapride was shown to significantly enhance gastric accommodation [19], Similarly, the efficacy of cisapride (a 5-HT4 agonist) was reported to be similar to that of placebo in FD patients, irrespective of their $\mathrm{H}$. pylori or gastritis status [20-22]. In contrast, cisapride was shown to alleviate symptoms in FD patients who were unresponsive to dopamine antagonist therapy [23], and was effective and safe in FD patients in a study from Saudi Arabia [24]. Tandospirone citrate, a 5-HT1 agonist, was shown to improve the abdominal symptom score in FD patients [25], while R-137696, another 5-HT1A agonist, failed to improve symptoms or visceral hypersensitivity in FD patients [26]. A meta-analysis of 27 studies comparing the efficacy of domperidone, metoclopramide, cisapride, trimebutine, itopride, and mosapride showed that these prokinetic agents were significantly more effective at treating FD compared to placebo [10]. Similarly, data from other meta-analysis studies also suggested that prokinetic drugs such as metoclopramide, domperidone, cisapride, and mosapride had a significantly higher efficacy compared to placebo [27-30].

The major challenge in drawing conclusions from comparisons of previous studies was the high degree of variability in patient numbers, criteria for patient selection, therapeutic regimens, and response to placebo. In the present study, we aimed to analyze the efficacy of 5-HT4A and 5-HT1A in FD patients. We only analyzed studies which reported response rates, and we compared the improvement in symptom score between the treatment and placebo groups.

\section{Material and methods}

This meta-analysis reviewed a total of 31 studies which investigated the efficacy of serotonin receptor agonists in the treatment of FD. The search strategy involved a detailed review of the Medline, Cochrane, EMBASE, and Google Scholar databases (until November 27, 2015). Reference lists of relevant studies were hand-searched using the following keywords: serotonin receptor agonist, 5-hydroxytryptamine receptor agonist, and functional dyspepsia. The flow diagram for study selection is depicted in Figure 1.

\section{Selection criteria}

The inclusion criteria for this analysis were: 1) randomized controlled trials (RCTs), 2) studies evaluating patients with FD, 3) studies where patients were divided into an intervention group (treated with a serotonin receptor agonist) and a placebo group, and 4) studies which evaluated quantitative outcomes. Exclusion criteria for this analysis were: 1) non-RCT, cohort studies, case series, letters, comments, editorials, case reports; proceedings, personal communications and onearm studies, 2) studies investigating patients with organic gastrointestinal disease, patients who had undergone major abdominal surgery, or patients with a major physical illness, and 3) studies with no quantitative outcome reported. Studies in which patients were not treated with a 5-HT agonist were excluded.

\section{Study selection and data extraction}

Studies were identified by two independent reviewers based on the inclusion and exclusion criteria. Where there was uncertainty regarding eligibility, a third reviewer was consulted. Information/data that were extracted from the studies included the name of the first author, year of publication, study design, number of participants in each group, age and gender of the participants, diagnostic criteria of FD, protocol of intervention, duration of symptoms, and major outcomes.

\section{Outcome measures and quality assessment}

The primary outcomes evaluated were the response rate and abdominal symptoms score. The 

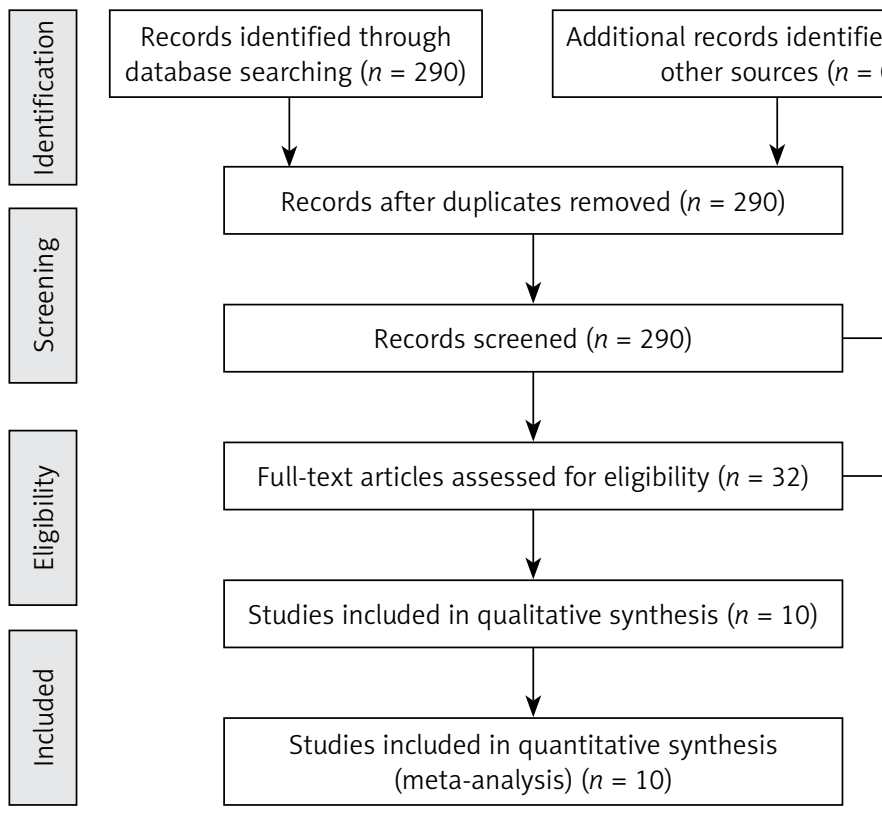

Records excluded after screening titles and abstracts $(n=258)$

Figure 1. PRISMA flow diagram

Cochrane Collaboration's tool was used to assess risk [31].

\section{Statistical analysis}

Event rates were extracted for dichotomous outcome variables (response rate), and mean and standard deviation were extracted for continuous outcomes (symptoms score). Odds ratios (OR) with 95\% confidence intervals $(\mathrm{Cl})$ were calculated for dichotomous outcomes between patients in the serotonin receptor agonist group and patients in the placebo group for all the studies combined. OR $>1$ indicated that the serotonin receptor agonist group was favored. Since the measurements of the symptoms scores were varied, the standardized mean difference (SMD) and corresponding 95\% confidence interval $(\mathrm{Cl})$ were calculated for the difference in the mean change of symptoms score between the groups. (SMD = difference in mean of outcome between groups/standard deviation of outcome among groups). If SMD was less than 0 , the serotonin receptor agonist group was favored. A $\chi^{2}$-based test of homogeneity was performed and the inconsistency index $\left(R^{2}\right)$ and $\mathrm{Q}$ statistics were determined. If the $R^{2}$ statistic was $>50 \%$, a random-effects model was used. Otherwise, a fixed-effect model was employed. Pooled effects were calculated and a 2-sided $p$-value $<0.05$ was considered statistically significant. Sensitivity analysis was carried out using the leave-one-out approach. A publication bias analysis was not performed due to the limited number of studies [32]. All analyses were performed using the Comprehensive Meta-Analysis Statistical Software, Version 2.0 (Biostat, Englewood, NJ, USA).

\section{Results}

Of the 31 studies initially evaluated for this meta-analysis, 21 studies were excluded based on the exclusion criteria, and a total of 10 RCTs were included in the final analysis. The meta-analysis therefore included a final total of 892 patients with FD who were assigned to the serotonin receptor agonist group, and 640 participants who were assigned to the placebo group. The protocols of interventions are summarized in Table I. Four of the studies were conducted in Europe, 4 in Asia, 1 in the USA, and 1 in Australia. The most common serotonin receptor agonist used was $5-\mathrm{HT} 4 \mathrm{~A}$ (8 studies), while 2 studies used 5 -HT1A. Table II shows the characteristics of the 10 RCTs. The average age of the study participants ranged from 32.5 to 50 years, and the percentage of male participants in the various studies ranged from $0 \%$ to $53 \%$. The duration of symptoms ranged from < 3 months [18] to 7.3 years [26]. Three studies included the $H$. pylori status of the study participants [18, 20, 25], four studies included the smoking status of study participants [18, 20, 22, 25], and five studies reported the alcohol use of the study participants [20-22, 25, 26].

\section{Meta-analysis}

Among the 8 studies which reported response rates, the response rates of study participants in the treatment group and the placebo group were compared using forest plots (Figure $2 \mathrm{~A}$ ). Two studies $[26,33]$ which did not provide response rates were excluded from the analysis. Since there was heterogeneity among the studies, all comparisons used a random-effects model $(Q$ statistic $=98.861$, 


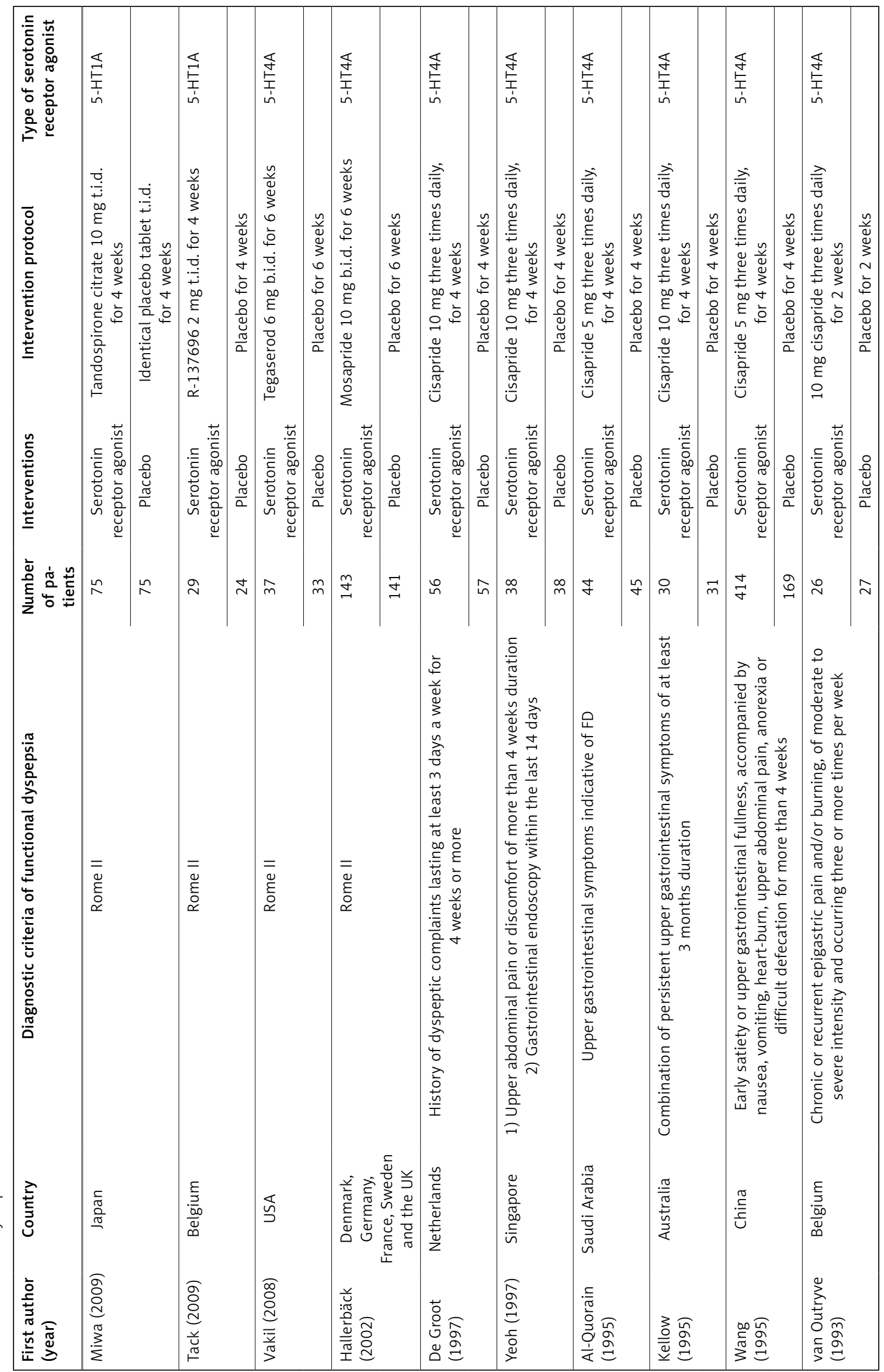


Table II. Summary of basic characteristics of selected studies for meta-analysis

\begin{tabular}{|c|c|c|c|c|c|c|c|c|}
\hline $\begin{array}{l}\text { First } \\
\text { author } \\
\text { (year) }\end{array}$ & $\begin{array}{l}\text { Number } \\
\text { of pa- } \\
\text { tients }\end{array}$ & Interventions & $\begin{array}{c}\text { Age } \\
\text { [years] }\end{array}$ & $\begin{array}{c}\text { Male } \\
(\%)\end{array}$ & Symptom duration & $\begin{array}{l}\text { Helicobacter } \\
\text { pylori } \\
\text { status (+) }\end{array}$ & Smoking & $\begin{array}{c}\text { Alcohol } \\
\text { use }\end{array}$ \\
\hline \multirow[t]{2}{*}{$\begin{array}{l}\text { Miwa } \\
\text { (2009) }\end{array}$} & 75 & $\begin{array}{l}\text { Serotonin } \\
\text { receptor } \\
\text { agonist }\end{array}$ & 46.2 & 24.0 & 12 months* & $20 \%$ & $10.7 \%$ & $34.7 \%$ \\
\hline & 75 & Placebo & 46.5 & 29.7 & 12 months* & $21.60 \%$ & $10.7 \%$ & $32.0 \%$ \\
\hline \multirow[t]{2}{*}{$\begin{array}{l}\text { Tack } \\
(2009)\end{array}$} & 29 & $\begin{array}{l}\text { Serotonin } \\
\text { receptor } \\
\text { agonist }\end{array}$ & 40.5 & 41.4 & 7.3 years & NA & NA & $44.8 \%$ \\
\hline & 24 & Placebo & 39.2 & 25.0 & 4.1 years & NA & NA & $54.2 \%$ \\
\hline \multirow[t]{2}{*}{$\begin{array}{l}\text { Vakil } \\
(2008)\end{array}$} & 37 & $\begin{array}{l}\text { Serotonin } \\
\text { receptor } \\
\text { agonist }\end{array}$ & 47.9 & 0.0 & NA & NA & NA & NA \\
\hline & 33 & Placebo & 48.7 & 0.0 & NA & NA & NA & NA \\
\hline \multirow[t]{2}{*}{$\begin{array}{l}\text { Hallerbäck } \\
\text { (2002) }\end{array}$} & 143 & $\begin{array}{l}\text { Serotonin } \\
\text { receptor } \\
\text { agonist }\end{array}$ & $\begin{array}{c}25-50: \\
47 \%\end{array}$ & 34.0 & $\begin{array}{c}<3 \text { months: } 1 \% \\
3 \text { months to } 1 \text { year: } 28 \% \\
>1 \text { year: } 71 \%\end{array}$ & $29 \%$ & NA & NA \\
\hline & 141 & Placebo & $\begin{array}{c}25-50: \\
52 \%\end{array}$ & 31.0 & $\begin{array}{c}<3 \text { months: } 0 \\
3 \text { months to } 1 \text { year: } 27 \% \\
>1 \text { year: } 73 \%\end{array}$ & $30 \%$ & NA & NA \\
\hline \multirow[t]{2}{*}{$\begin{array}{l}\text { De Groot } \\
\text { (1997) }\end{array}$} & 56 & $\begin{array}{l}\text { Serotonin } \\
\text { receptor } \\
\text { agonist }\end{array}$ & 40.9 & 39.3 & 88.8 weeks & $17.90 \%$ & $41.1 \%$ & $53.6 \%$ \\
\hline & 57 & Placebo & 43.9 & 52.6 & 61.0 weeks & $36.40 \%$ & $33.3 \%$ & $49.1 \%$ \\
\hline \multirow[t]{2}{*}{$\begin{array}{l}\text { Yeoh } \\
\text { (1997) }\end{array}$} & 38 & $\begin{array}{l}\text { Serotonin } \\
\text { receptor } \\
\text { agonist }\end{array}$ & 38.5 & 44.7 & NA & NA & $5.3 \%$ & $0.0 \%$ \\
\hline & 38 & Placebo & 40.8 & 44.7 & NA & NA & $7.9 \%$ & $7.9 \%$ \\
\hline \multirow[t]{2}{*}{$\begin{array}{l}\text { Al-Quorain } \\
\text { (1995) }\end{array}$} & 44 & $\begin{array}{c}\text { Serotonin } \\
\text { receptor } \\
\text { agonist }\end{array}$ & 32.5 & 50.0 & $\begin{array}{c}>6 \text { weeks }<1 \text { year: } 4 \% \\
1 \text { year: } 16 \% \\
\text { Several years: } 80 \%\end{array}$ & NA & NA & NA \\
\hline & 45 & Placebo & 33.7 & $51.1 \%$ & $\begin{array}{c}>6 \text { weeks }<1 \text { year: } 6 \% \\
1 \text { year: } 16 \% \\
\text { Several years: } 78 \%\end{array}$ & NA & NA & NA \\
\hline \multirow[t]{2}{*}{$\begin{array}{l}\text { Kellow } \\
\text { (1995) }\end{array}$} & 30 & $\begin{array}{l}\text { Serotonin } \\
\text { receptor } \\
\text { agonist }\end{array}$ & 50 & $33.3 \%$ & NA & NA & $7.0 \%$ & $47.0 \%$ \\
\hline & 31 & Placebo & 46 & $34.8 \%$ & NA & NA & $13.0 \%$ & $43.0 \%$ \\
\hline \multirow[t]{2}{*}{$\begin{array}{l}\text { Wang } \\
\text { (1995) }\end{array}$} & 414 & $\begin{array}{l}\text { Serotonin } \\
\text { receptor } \\
\text { agonist }\end{array}$ & 43.4 & $47.8 \%$ & $\begin{array}{c}<0.5 \text { year: } 54.1 \% \\
0.5-1.0 \text { year: } 14.7 \% \\
1.1-2.0 \text { years: } 12.8 \% \\
2.1-5.0 \text { years: } 9.9 \% \\
>5.0 \text { years: } 8.5 \%\end{array}$ & NA & NA & NA \\
\hline & 169 & Placebo & 41.2 & $41.4 \%$ & $\begin{array}{c}<0.5 \text { year: } 62.7 \% \\
0.5-1.0 \text { year: } 17.8 \% \\
1.1-2.0 \text { years: } 11.8 \% \\
2.1-5.0 \text { years: } 4.1 \% \\
>5.0 \text { years: } 3.6 \%\end{array}$ & NA & NA & NA \\
\hline \multirow[t]{2}{*}{$\begin{array}{l}\text { van } \\
\text { Outryve } \\
\text { (1993) }\end{array}$} & 26 & $\begin{array}{l}\text { Serotonin } \\
\text { receptor } \\
\text { agonist }\end{array}$ & 43 & $42.3 \%$ & 12.5 months & NA & NA & NA \\
\hline & 27 & Placebo & 43 & $37.0 \%$ & 7.3 months & NA & NA & NA \\
\hline
\end{tabular}


A

\begin{tabular}{lccccc} 
First author & \multicolumn{6}{c}{ Statistics for each study } \\
\cline { 2 - 7 } (year) & $\begin{array}{c}\text { Odds } \\
\text { ratio }\end{array}$ & $\begin{array}{c}\text { Lower } \\
\text { limit }\end{array}$ & $\begin{array}{c}\text { Upper } \\
\text { limit }\end{array}$ & Z-value & $P$-value \\
\hline Miwa (2009) & 3.16 & 1.37 & 7.29 & 2.70 & 0.007 \\
Hallerbäck (2002) & 0.96 & 0.60 & 1.54 & -0.17 & 0.86 \\
De Groot (1997) & 2.17 & 1.02 & 4.60 & 2.01 & 0.04 \\
Yeoh (1997) - Gastritis & 1.56 & 0.42 & 5.82 & 0.66 & 0.510 \\
Yeoh (1997) - No gastritis & 1.04 & 0.30 & 3.61 & 0.06 & 0.950 \\
Al-Quorain (1995) & 17.90 & 6.00 & 53.36 & 5.18 & $<0.001$ \\
Kellow (1995) & 0.72 & 0.24 & 2.15 & -0.59 & 0.553 \\
Wang (1995) & 18.76 & 11.54 & 30.50 & 11.83 & $<0.001$ \\
van Outryve (1993) & 6.58 & 1.95 & 22.21 & 3.04 & 0.002 \\
Pooled effect & 2.99 & 1.15 & 7.77 & 2.25 & 0.025
\end{tabular}

Odds ratio and $95 \% \mathrm{Cl}$

Relative

weight

Heterogeneity test: $\mathrm{Q}=98.861, \mathrm{~d} f=8, p<0.001, I^{2}=91.91 \%$

.007
.864
.044
.510
.950
0.001
.553
0.001
.002
0.025

the

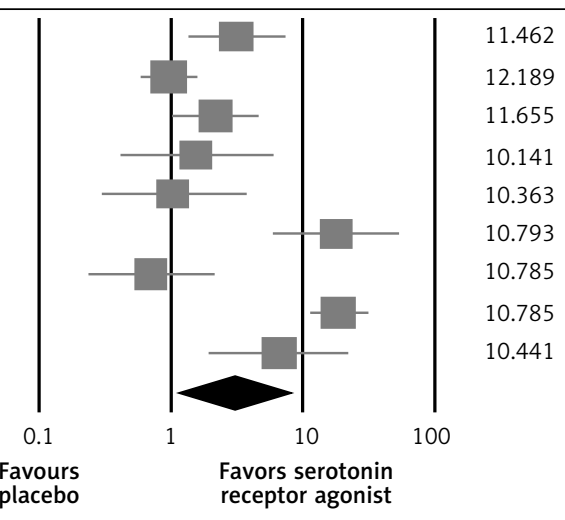

B

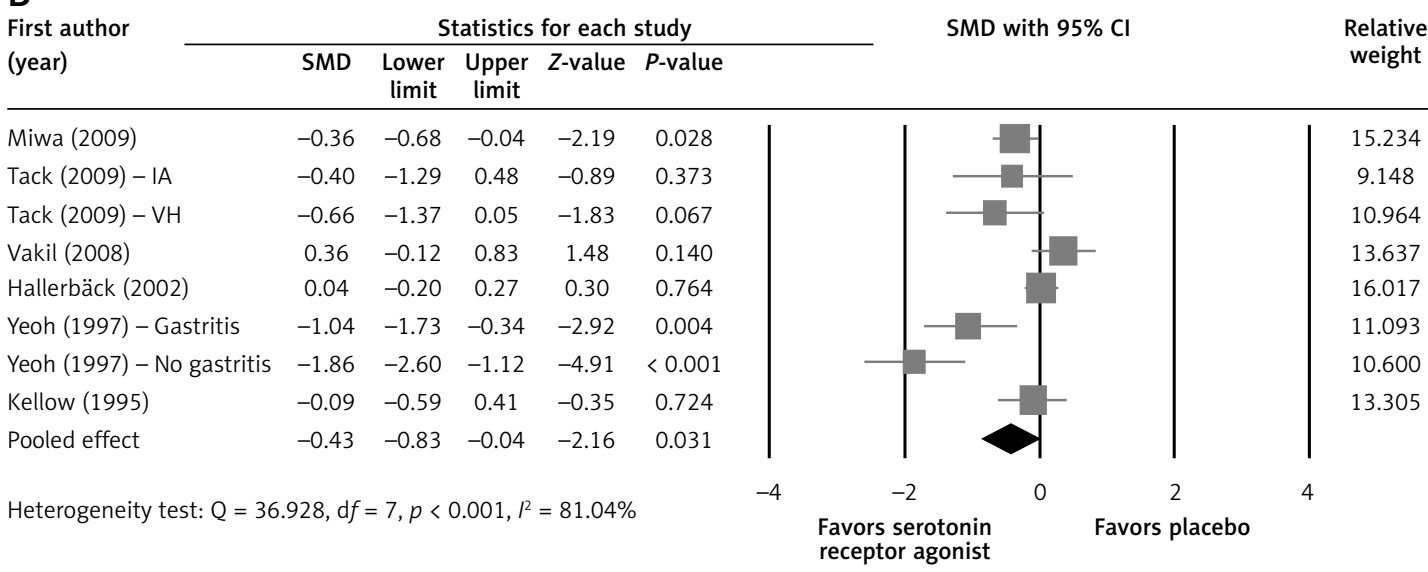

Figure 2. Forest plots for efficacy of serotonin receptor agonists on (A) response rate, (B) abdominal symptoms score

$\left.r^{2}=91.91 \%\right)$. The final analysis showed a significantly higher response rate in patients treated with the serotonin receptor agonists compared to patients in the placebo group (pooled OR = 2.99; $95 \% \mathrm{Cl}: 1.15-7.77 ; p=0.025)$.

The difference in mean change of abdominal symptoms score between the treatment and placebo groups was analyzed using a random effects model (Q statistic $=36.928, R^{2}=81.04 \%$ ) (Figure 2 B). The improvement in symptom scores was significantly larger in the group treated with the serotonin receptor agonists compared to the placebo group (pooled SDM $=-0.43 ; 95 \% \mathrm{Cl}$ : -0.83 to -0.04 ; $p=0.031)$

Sensitivity analyses were performed using the leave-one-out approach, where the meta-analysis was performed after removing one study at a time (Table III). After each study was removed individually, the pooled estimates on response rate remained in the same directions, although 2 data points [23, $24]$ became non-significant ( $p$-values were at the borderline), which indicated an acceptable robustness of the pooled estimates. However, our results indicated that the pooled estimates for symptoms score could be affected by the Yeoh et al. "no gastritis" study [21]. After removal of the Yeoh et al. study from the analysis, there was no statistically significant difference in the mean change of symptoms score between the two groups (pooled SMD $=-0.23,95 \% \mathrm{Cl}:-0.53$ to $0.07, p=0.131$ ).

\section{Quality assessment}

The Cochrane Collaboration's tool for assessing risk was used for quality assessment. The assessed outcomes for the included studies are described in Figure 3. There was a low risk of bias in random sequence generation, incomplete outcome data and selective reporting in all the included studies. Most of the included studies also had a low risk of bias in blinding of participants, personnel and outcome assessment. However, seven studies had an unclear risk of bias in allocation concealment, and five studies had an unclear risk of bias in the intention-to-treat analysis. Overall the included studies had a low risk of performance bias, detection bias, attrition bias, and reporting bias, while the risk of bias in selection and intention-to-treat analysis was unclear. 
Table III. Sensitivity analysis

\begin{tabular}{|c|c|c|c|c|c|}
\hline \multirow[t]{2}{*}{ First author (year) } & \multicolumn{5}{|c|}{ Statistics with study removed } \\
\hline & Points & Lower limit & Upper limit & $Z$-value & $P$-value \\
\hline \multicolumn{6}{|l|}{ Response rate: } \\
\hline Miwa (2009) & 2.96 & 1.00 & 8.76 & 1.96 & 0.049 \\
\hline Hallerbäck (2002) & 3.52 & 1.36 & 9.08 & 2.60 & 0.009 \\
\hline De Groot (1997) & 3.11 & 1.04 & 9.27 & 2.04 & 0.041 \\
\hline Yeoh (1997) - Gastritis & 3.22 & 1.15 & 9.02 & 2.22 & 0.026 \\
\hline Yeoh (1997) - No gastritis & 3.38 & 1.21 & 9.40 & 2.33 & 0.020 \\
\hline Al-Quorain (1995) & 2.41 & 0.88 & 6.57 & 1.72 & 0.086 \\
\hline Kellow (1995) & 3.55 & 1.29 & 9.76 & 2.46 & 0.014 \\
\hline Wang (1995) & 2.29 & 1.12 & 4.66 & 2.28 & 0.023 \\
\hline van Outryve (1993) & 2.72 & 0.96 & 7.69 & 1.89 & 0.059 \\
\hline \multicolumn{6}{|l|}{ Symptoms score: } \\
\hline Miwa (2009) & -0.47 & -0.96 & 0.03 & -1.86 & 0.063 \\
\hline Tack (2009) - IA & -0.44 & -0.87 & -0.01 & -2.03 & 0.043 \\
\hline Tack (2009) - VH & -0.41 & -0.84 & 0.02 & -1.88 & 0.061 \\
\hline Vakil (2008) & -0.56 & -0.98 & -0.14 & -2.59 & 0.010 \\
\hline Hallerbäck (2002) & -0.53 & -1.01 & -0.06 & -2.19 & 0.029 \\
\hline Yeoh (1997) - Gastritis & -0.35 & -0.76 & 0.05 & -1.72 & 0.086 \\
\hline Yeoh (1997) - No gastritis & -0.23 & -0.53 & 0.07 & -1.51 & 0.131 \\
\hline Kellow (1995) & -0.50 & -0.95 & -0.04 & -2.14 & 0.032 \\
\hline
\end{tabular}

\section{Discussion}

This meta-analysis included 10 RCTs which evaluated the efficacy of serotonin receptor agonists in patients with FD. Our analysis showed that patients treated with serotonin receptor agonists 5-HT4A or 5-HT1A had a significantly higher response rate compared to placebo-treated patients. The treatment groups also had a significantly larger improvement in symptom scores compared to the placebo groups.

The most common adverse event reported in the included studies was diarrhea.

Serotonin (5-hydroxytryptamine) is an important neurotransmitter in the brain as well as in the gastrointestinal tract, where it plays a key role in the regulation of sensory and motor functions [17]. A number of serotonin receptor subtypes have been investigated as therapeutic targets for modulation of gastrointestinal motility, secretion, and sensation [34]. Serotonergic agents which have been used as therapeutic agents include 5-HT1A agonists, 5-HT1B/D agonists, 5-HT2A antagonists, 5-HT3 antagonists, and 5-HT4 agonists $[25,35]$. Tandospirone citrate is a $5-\mathrm{HT} 1 \mathrm{~A}$ agonist which has been used for treatment of anxiety and psychosomatic disorders, and significantly improved abdominal symptom scores in FD patients [25]. R-137696 is also a 5-HT1A agonist which has been shown to relax the proximal stomach in a dose-dependent manner [26]. Mosapride and tegaserod are also 5-HT4 agonists which have been shown to improve symptoms, and enhance gastric accommodation in FD patients [36, 37], although other data from a recent meta-analysis showed that mosapride had no significant therapeutic effect on FD [38]. Additionally, gastroprokinetics (cisapride and domperidone) as well as histamine $\mathrm{H} 2$ receptor antagonists were reported to have a significantly higher efficacy in relieving FD symptoms compared to placebo, and gastroprokinetics had a higher efficacy compared to histamine $\mathrm{H} 2$ receptor antagonists [28, 39].

Our present study analyzed the efficacy of serotonin receptor agonists in the treatment of FD. We included six studies which evaluated the efficacy of cisapride vs. placebo [20-24, 40], one study which evaluated the efficacy of mosapride vs. placebo [18], one study which evaluated the efficacy of tegaserod vs. placebo [33], one study which evaluated the efficacy of R-137696 vs. placebo 
A

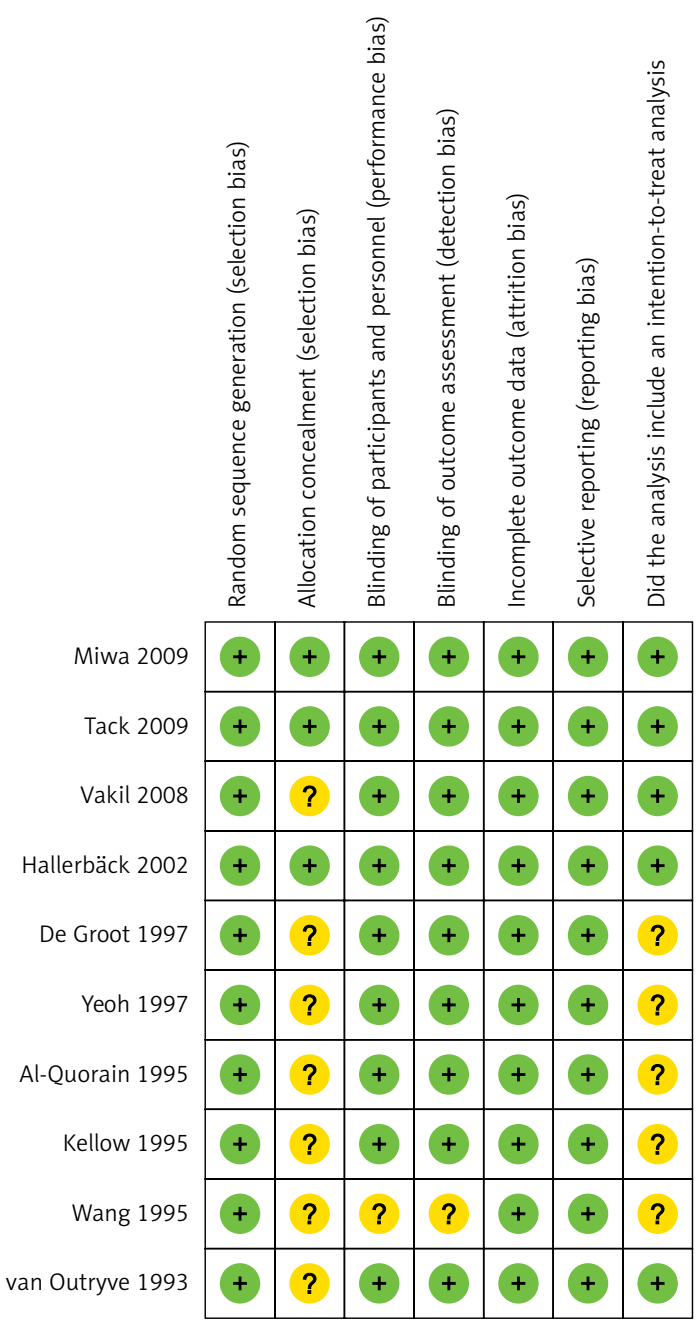

B

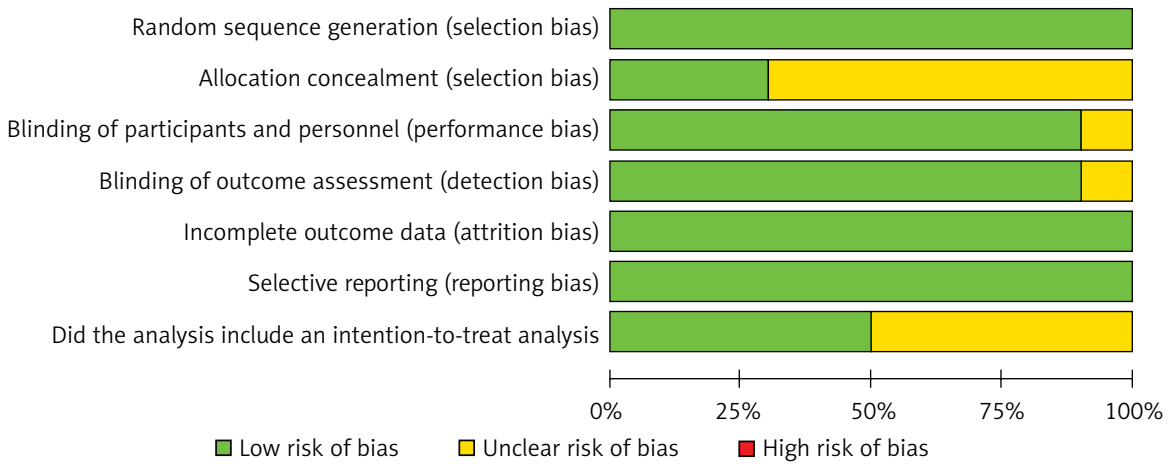

Figure 3. Quality assessment individual studies (A), overall quality (B)

[26], and one study which evaluated the efficacy of tandospirone citrate vs. placebo [25]. Response rates were reported in 8 of these studies. Our random effects model analysis showed that patients treated with a 5-HT1 or 5-HT4 agonist had significantly higher response rates, and a significantly larger improvement in symptom scores compared to placebo-treated patients. Our data were consistent with a number of studies investigating the efficacy of cisapride, a 5-HT4 agonist and 5-HT3 antagonist, which reported a significant improvement of dys- peptic symptoms and acceleration of gastric emptying in cisapride-treated FD patients compared to placebo-treated patients [41-43]. A previous study showed that $5 \mathrm{mg}$ of cisapride was equally effective as the $10 \mathrm{mg}$ dose when administered three times daily, although the higher dose was more effective at relieving reflux symptoms [24]. However, cisapride has been withdrawn in many countries because its use was associated with QT prolongation, which could be fatal [44]. In our present meta-analysis, four studies used $10 \mathrm{mg}$ of cisapride ad- 
ministered three times daily, and two studies used $5 \mathrm{mg}$ of cisapride administered three times daily. Our sensitivity analysis showed that, after removing one study at a time, the pooled estimates of response rate remained in the same direction.

Our present analysis only included studies which compared the efficacy of different agonists with that of a placebo. Head-to-head comparison studies are necessary to determine the best 5-HT agonist (e.g. cisapride versus mosapride) for the treatment of FD, in the context of efficacy, cost, and availability. The treatment period in our included studies ranged from 2 weeks to 6 weeks. However, based on findings that drugs like tandospirone citrate work gradually, and that FD is a chronic condition that persists over several years, it will be important to evaluate long-term studies of efficacy of these therapeutic agents. Although 4 of the included studies reported the smoking status, 5 studies reported alcohol use, and 3 studies reported the $H$. pylori status of the study participants, the correlations of these variables with FD remain unclear. It is important to determine the role of $\mathrm{H}$. pylori status and presence of gastritis in the response to 5-HT agonists.

In conclusion, our meta-analysis of 10 studies which investigated the efficacy of $5-\mathrm{HT} 1$ and 5-HT4 agonists in FD patients showed significantly higher response rates and improvement of symptoms in patients treated with the serotonin receptor agonists compared to the placebo group. It is important to evaluate a larger number of serotonin receptor subtypes over longer treatment periods, and increase the sample size, along with a careful review of inclusion/exclusion criteria to control for the high reported rates of response to placebo, and for the heterogeneity in patient selection criteria among different studies. It is also important to evaluate the role of factors such as $H$. pylori status in response rates to $5-\mathrm{HT} 1$ and 5-HT4 in FD patients.

\section{Conflict of interest}

The authors declare no conflict of interest.

\section{References}

1. Tack J, Talley NJ, Camilleri M, et al. Functional gastroduodenal disorders. Gastroenterology 2006; 130: 1466-79.

2. Talley NJ, Stanghellini V, Heading RC, Koch KL, Malagelada JR, Tytgat GN. Functional gastroduodenal disorders. Gut 1999; 45 Suppl 2: ॥137-42.

3. Talley NJ. Drug treatment of functional dyspepsia. Scand J Gastroenterol Suppl 1991; 182: 47-60.

4. Ford AC, Marwaha A, Sood R, Moayyedi P. Global prevalence of, and risk factors for, uninvestigated dyspepsia: a meta-analysis. Gut 2015; 64: 1049-57.

5. Yarandi SS, Christie J. Functional dyspepsia in review: pathophysiology and challenges in the diagnosis and management due to coexisting gastroesophageal reflux disease and irritable bowel syndrome. Gastroenterol Res Pract 2013; 2013: 351086.

6. Armstrong D. Helicobacter pylori infection and dyspepsia. Scand J Gastroenterol Suppl 1996; 215: 38-47.

7. Gisbert JP, Calvet X, Gabriel R, Pajares JM. [Helicobacter pylori infection and functional dyspepsia. Meta-analysis of efficacy of eradication therapy]. Med Clin (Barc) 2002; 118: 405-9.

8. Moayyedi P, Soo S, Deeks J, et al. Systematic review and economic evaluation of Helicobacter pylori eradication treatment for non-ulcer dyspepsia. Dyspepsia Review Group. BMJ 2000; 321: 659-64.

9. Du LJ, Chen BR, Kim JJ, Kim S, Shen JH, Dai N. Helicobacter pylori eradication therapy for functional dyspepsia: systematic review and meta-analysis. World J Gastroenterol 2016; 22: 3486-95.

10. Hiyama T, Yoshihara M, Matsuo K, et al. Meta-analysis of the effects of prokinetic agents in patients with functional dyspepsia. J Gastroenterol Hepatol 2007; 22: 304-10.

11. Lu Y, Chen M, Huang Z, Tang C. Antidepressants in the treatment of functional dyspepsia: a systematic review and meta-analysis. PLoS One 2016; 11: e0157798.

12. Talley NJ. Functional dyspepsia: new insights into pathogenesis and therapy. Korean J Intern Med 2016; 31: 444-56.

13. Talley NJ; American Gastroenterological A. American Gastroenterological Association medical position statement: evaluation of dyspepsia. Gastroenterology 2005; 129: 1753-5.

14. Moayyedi P, Soo S, Deeks J, Delaney B, Innes M, Forman D. Pharmacological interventions for non-ulcer dyspepsia. Cochrane Database Syst Rev 2006; 4: CD001960.

15. Huang X, Lv B, Zhang S, Fan YH, Meng LN. Itopride therapy for functional dyspepsia: a meta-analysis. World J Gastroenterol 2012; 18: 7371-7.

16. Degen L, Petrig C, Studer D, Schroller S, Beglinger C. Effect of tegaserod on gut transit in male and female subjects. Neurogastroenterol Motil 2005; 17: 821-6.

17. Mawe GM, Hoffman JM. Serotonin signalling in the gutfunctions, dysfunctions and therapeutic targets. Nat Rev Gastroenterol Hepatol 2013; 10: 473-86.

18. Hallerback BI, Bommelaer G, Bredberg E, et al. Dose finding study of mosapride in functional dyspepsia: a placebo-controlled, randomized study. Aliment Pharmacol Ther 2002; 16: 959-67.

19. Amano T, Ariga H, Kurematsu A, et al. Effect of 5-hydroxytryptamine receptor 4 agonist mosapride on human gastric accommodation. Neurogastroenterol Motil 2015; 27: 1303-9.

20. de Groot GH, de Both PS. Cisapride in functional dyspepsia in general practice. A placebo-controlled, randomized, double-blind study. Aliment Pharmacol Ther 1997; 11: 193-9.

21. Yeoh KG, Kang JY, Tay HH, et al. Effect of cisapride on functional dyspepsia in patients with and without histological gastritis: a double-blind placebo-controlled trial. J Gastroenterol Hepatol 1997; 12: 13-8.

22. Kellow JE, Cowan H, Shuter B, et al. Efficacy of cisapride therapy in functional dyspepsia. Aliment Pharmacol Ther 1995; 9: 153-60.

23. Van Outryve M, De Nutte N, Van Eeghem P, Gooris JP. Efficacy of cisapride in functional dyspepsia resistant to domperidone or metoclopramide: a double-blind, placebo-controlled study. Scand J Gastroenterol Suppl 1993; 195: 47-52; discussion-3.

24. al-Quorain A, Larbi EB, al-Shedoki F. A double-blind, randomized, placebo-controlled trial of cisapride in Saudi 
Arabs with functional dyspepsia. Scand J Gastroenterol 1995; 30: 531-4.

25. Miwa $H$, Nagahara A, Tominaga $K$, et al. Efficacy of the 5-HT1A agonist tandospirone citrate in improving symptoms of patients with functional dyspepsia: a randomized controlled trial. Am J Gastroenterol 2009; 104: 2779-87.

26. Tack J, Van Den Elzen B, Tytgat G, et al. A placebo-controlled trial of the 5-HT1A agonist R-137696 on symptoms, visceral hypersensitivity and on impaired accommodation in functional dyspepsia. Neurogastroenterol Motil 2009; 21: 619-26, e23-4.

27. Hiyama T, Yoshihara M, Matsuo K, et al. Treatment of functional dyspepsia with serotonin agonists: a metaanalysis of randomized controlled trials. J Gastroenterol Hepatol 2007; 22: 1566-70.

28. Allescher HD, Bockenhoff A, Knapp G, Wienbeck M, Hartung J. Treatment of non-ulcer dyspepsia: a meta-analysis of placebo-controlled prospective studies. Scand J Gastroenterol 2001; 36: 934-41.

29. Veldhuyzen van Zanten SJ, Jones MJ, Verlinden M, Talley NJ. Efficacy of cisapride and domperidone in functional (nonulcer) dyspepsia: a meta-analysis. Am J Gastroenterol 2001; 96: 689-96.

30. Dobrilla G, Comberlato M, Steele A, Vallaperta P. Drug treatment of functional dyspepsia. A meta-analysis of randomized controlled clinical trials. J Clin Gastroenterol 1989; 11: 169-77.

31. Collaboration TC. Cochrane Handbook for Systematic. Reviews of Interventions. Version 5.1.0 Updated March 2011.

32. Sterne JA, Sutton AJ, Ioannidis JP, et al. Recommendations for examining and interpreting funnel plot asymmetry in meta-analyses of randomised controlled trials. BMJ 2011; 343: d4002.

33. Vakil N, Kianifard F, Bottoli I. Exploratory study of tegaserod for dyspepsia in women receiving PPIs for heartburn. Arch Drug Inf 2008; 1: 79-88.

34. Gershon MD, Tack J. The serotonin signaling system: from basic understanding to drug development for functional GI disorders. Gastroenterology 2007; 132: 397-414.

35. Camilleri M. Functional dyspepsia and gastroparesis. Dig Dis 2016; 34: 491-9.

36. Hongo M, Harasawa S, Mine T, et al. Large-scale randomized clinical study on functional dyspepsia treatment with mosapride or teprenone: Japan Mosapride Mega-Study (JMMS). J Gastroenterol Hepatol 2012; 27: 62-8.

37. Tack J, Janssen P, Bisschops R, Vos R, Phillips T, Tougas G. Influence of tegaserod on proximal gastric tone and on the perception of gastric distention in functional dyspepsia. Neurogastroenterol Motil 2011; 23: e32-9.

38. Bang CS, Kim JH, Baik GH, et al. Mosapride treatment for functional dyspepsia: a meta-analysis. J Gastroenterol Hepatol 2015; 30: 28-42.

39. Redstone HA, Barrowman N, Veldhuyzen Van Zanten SJ. $\mathrm{H} 2$-receptor antagonists in the treatment of functional (nonulcer) dyspepsia: a meta-analysis of randomized controlled clinical trials. Aliment Pharmacol Ther 2001; 15: 1291-9.

40. Wang B, Liang X, Jia B. [A controlled multi-centre clinical trial on cisapride in treatment of functional dyspepsia]. Zhonghua Nei Ke Za Zhi 1995; 34: 180-4.

41. Rosch W. Cisapride in non-ulcer dyspepsia. Results of a placebo-controlled trial. Scand J Gastroenterol 1987, 22: 161-4.
42. Jian R, Ducrot F, Ruskone A, et al. Symptomatic, radionuclide and therapeutic assessment of chronic idiopathic dyspepsia. A double-blind placebo-controlled evaluation of cisapride. Dig Dis Sci 1989; 34: 657-64.

43. Corinaldesi R, Stanghellini V, Raiti C, Rea E, Salgemini R, Barbara L. Effect of chronic administration of cisapride on gastric emptying of a solid meal and on dyspeptic symptoms in patients with idiopathic gastroparesis. Gut 1987; 28: 300-5.

44. Karamanolis GP, Tack J. Current management of functional dyspepsia: impact of Rome III subdivision. Ann Gastroenterol 2012; 25: 96-9. 